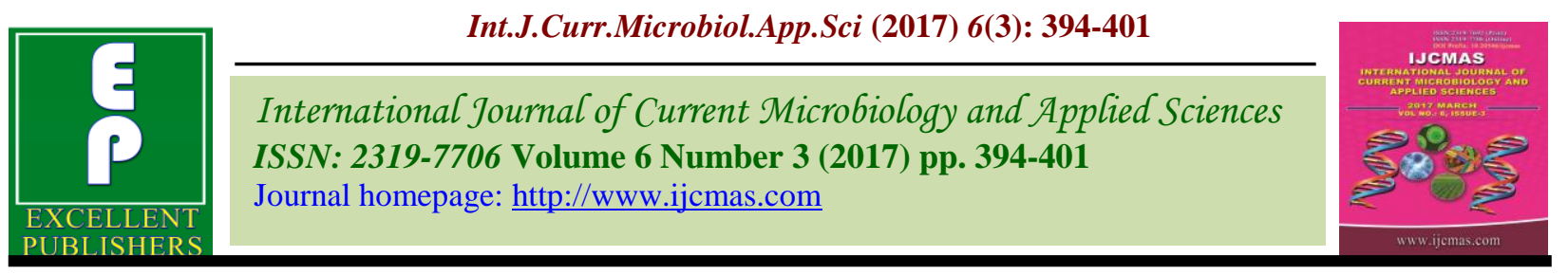

Original Research Article https://doi.org/10.20546/ijcmas.2017.603.045

\title{
Effect of Temperature on Growth and Sporulation of Rice Leaf Blast Pathogen Magnaporthe oryzae
}

\author{
Laxman Singh Rajput*, Taru Sharma, Puchakayala Madhusudhan and Parimal Sinha
}

\author{
Division of Plant Pathology, ICAR-Indian Agricultural Research Institute, \\ New Delhi-110012, India \\ *Corresponding author
}

\begin{tabular}{|c|c|}
\hline & A B S T R A C T \\
\hline & $\begin{array}{l}\text { Temperature rise due to climate change is expected to change pathogenicity of the } \\
\text { pathogen. Temperature has a significant influence on growth and sporulation of rice leaf }\end{array}$ \\
\hline Keywords & $\begin{array}{l}\text { blast pathogen }(M \text {. oryzae }) \text {. Both growth and sporulation were increased up to a } \\
\text { temperature }\left(27^{\circ} \mathrm{C}\right) \text { and declined further in response to increased or decreased with }\end{array}$ \\
\hline $\begin{array}{l}\text { Leaf blast, Growth, } \\
\text { Sporulation, } \\
\text { Temperature. }\end{array}$ & $\begin{array}{l}\text { temperature }\left(32^{\circ} \mathrm{C} \text { and } 22^{\circ} \mathrm{C}\right) \text {. Various components of rice blast infection observed } \\
\text { maximum at } 27^{\circ} \mathrm{C} \text { (optimal temperature) compared to suboptimal }\left(22^{\circ} \mathrm{C}\right) \text { and supra- } \\
\text { optimal }\left(32^{\circ} \mathrm{C}\right) \text { i.e. growth and rate of growth in RSEDOMA media, lesion development }\end{array}$ \\
\hline Article Info & $\begin{array}{l}\text { and rate of lesion development in susceptible variety PRR78, sporulation and rate of } \\
\text { sporulation in RSEDOMA media and susceptible variety PRR78. Rise in temperature }\end{array}$ \\
\hline $\begin{array}{l}\text { Accepted: } \\
\text { 10 February } 2017 \\
\text { Available Online: } \\
10 \text { March } 2017\end{array}$ & $\begin{array}{l}\text { leads to increase in growth and sporulation of } M \text {. oryzae in tropical and subtropical regions } \\
\text { of the world, it's to be expected to enhance in aggressiveness of } M \text {. oryzae that results rice } \\
\text { blast epidemic in tropical and subtropical regions of the world. Therefore, the impact of } \\
\text { temperature on infection components may use for development of crop loss assessment }\end{array}$ \\
\hline & $\begin{array}{l}\text { moders, rice blast prediction models, evaluation of genotypes for the development or } \\
\text { future plant diseases managements strategies. }\end{array}$ \\
\hline
\end{tabular}

\section{Introduction}

Rice (Oryza sativa) is such an important cereal crop, which could provide $20 \%$ of total energy intake worldwide and lead staple food for $>50 \%$ of world's inhabitants (FAO, 2014). Among 36 fungal diseases of rice, rice blast caused by Magnaporthe oryzae (Herbert) is very notorious pathogen to decline rice world's production by $\sim 8 \%$ per year (Wilson and Talbot, 2009). With this capacity, it shows that rice blast outbreaks are the serious and recurrent problem in all rice-growing regions of the world. In India, rice blast is a serious concern due to favourable climatic condition during the crop season. Weather plays an important role in the appearance, multiplication and spread of blast fungus. Minimum night temperature which needed for blast epidemic is ranges from $20^{\circ}-26^{\circ} \mathrm{C}$, with the association of $>90 \%$ of relative humidity, dew deposit, extended leaf wetness period (> $10 \mathrm{~h}$ ) and cloudy drizzling weather during any crop growth stage of susceptible varieties (Padmanabhan, 1965). The interaction among a susceptible host plants, a virulent pathogens and the environment results in plant diseases. Various changes in climatic conditions are always associated with disease levels because the climatic conditions 
significantly influence plants, pathogens and their antagonists. Pathogen biology may be directly influenced by climatic conditions in quite a lot of ways. The progressing periods of encouraging temperature, rainfall and relative humidity $(\mathrm{RH})$ those near to the optimal conditions for the pathogen development and dispersal may lead to the incidence of ruthless epidemics. As temperature increases, most of the pathogens will be extend into new geographic areas with new potential hosts and more virulence. Temperature and $\mathrm{RH}$ also influence the pathogen survival during over wintering and over summering (Agrios, 2005).

Conidial germination, formation of appressoria and penetration are the important stages of infection process in $M$. oryzae. Various climatic condition influences infection process. $M$. oryzae requires $25-28^{\circ} \mathrm{C}$ (Sueda, 1928; Suzuki, 1969) and $16-32^{\circ} \mathrm{C}$ (Liang, 1979) of temperature ranges for conidial germination and while no germination of conidia occurred at $10-15^{\circ} \mathrm{C}$ (Nishikado, 1927). Spore germination in $M$. oryzae started within 3 hours after host tissues attachment at $18-38^{\circ} \mathrm{C}$ if it was wet (Kato, 1974) and delayed if dry period exposed (Kingsolver et al., 1984). Appressoria formation required a wide range of temperatures (Suzuki, 1969; Yoshino, 1972; Kato 1974; Rahnema, 1978). In in vitro, appressoria formation observed at the temperature of $21-30^{\circ} \mathrm{C}$ but interestingly $\mathrm{RH}$ had no impact on appressoria formation (El Refaei, 1977). Colonization of M. oryzae increased with increasing temperature up to $28^{\circ} \mathrm{C}$ and highest sporulation was possible at $20^{\circ} \mathrm{C}$ (Kato et al., 1970; Kato, 1974; Kato and Kozaka, 1974; El Refaei, 1977).

Global climate change, particularly increased in temperature and $\mathrm{CO}^{2}$ levels (IPCC, 2007) are the consideration to manipulate all the disease triangle elements i.e., host, pathogen and climate factors and their interactions
(Legreve and Duveiller, 2010). Thus, climate change may influence disease incidence and severity and also influence further coevolution of plants and their pathogens (Chakraborty, 2005; Burdon et al., 2006; Eastburn et al., 2011). Optimal temperature conditions for surviving of present species is available in tropical regions while pathogens surviving in cooler climates of higher latitudes required lower temperature; therefore, global warming is expected to their fitness enhance and the rise in epidemics risk of the disease with which they are associated (Ghini et al., 2011). The role of temperature on growth and development of $M$. oryzae is always under consideration for development of new simulation models; therefore the aim of this study was to determine the effect of temperature on growth and sporulation of Magnaporthe oryzae causing rice blast.

\section{Materials and Methods}

\section{Source of biological material}

To determine the effect of the three different temperatures $22, \quad 27$ and $32^{\circ} \mathrm{C}$ blast susceptible genotype PRR78 was used. Pusa basmati virulent isolate (MJ-24) of Magnaporthe oryzae obtained from IARI, PUSA, New Delhi-12.

Radial Growth on rice straw extract dextrose oat meal agar (RSEDOMA) media at three temperatures

The relative growth of $M$. oryzae was measured on RSEDOMA media (Rice Straw 20g; dextrose 20g; oat meal 20g; agar 20g; biotin 25ng; per litre distilled water). In RSEDOMA media at the centre of the Petriplate a mycelial disk $(0.4 \mathrm{~cm})$ was inoculated and incubated in the BOD at temperatures of $22,27,32^{\circ} \mathrm{C}$ respectively. Average relative growth was measured at $10^{\text {th }}$ day after incubation at respective temperature. 


\section{Sporulation on RSEDOMA media at three temperatures}

For sporulation induction, $M$. oryzae mycelial disk $(0.4 \mathrm{~cm})$ were inoculated in RSEDOMA media and kept in a BOD incubator (attached with black fluorescent tube of wavelength range of 350-390 nm) with cycles $14 \mathrm{~h}$ NearUV light and $10 \mathrm{~h}$ dark at set of temperatures of $22^{\circ}, 27^{\circ}, 32^{\circ} \mathrm{C}$ respectively (Yaegashi and Herbert, 1976; Talbot et al., 1993). For fluorescent light exposure, the slants were kept at $20 \mathrm{~cm}$ distance from the light source for induction of sporulation.

\section{Inoculation of plants for sporulation and lesion development}

PRR8 a susceptible variety was raised in polypropylene pots $(10 \times 10 \mathrm{~cm})$ filled with uniform soil mixture with optimum moisture supply. Six pots with three plants were prepared for each treatment. Inoculations were done at when the $6^{\text {th }}$ leaf was half emerged with @ $10^{5}$ conidia/ml of sterile water (Sharma et al., 2005) containing 0.02\% Tween 20 (Ghatak et al., 2013).

Plants were maintained in growth chamber 1 week before inoculation with nearly $70 \%$ of $\mathrm{RH}$ and day and night temperatures $26^{\circ} \mathrm{C}$ or $24^{\circ} \mathrm{C}$. Plants with mock inoculation (sterile water with $0.025 \%$ Tween 20 ) were used negative control. Plants were covered with black polythene bags and incubate under the dark condition at three different temperatures i.e., $22^{\circ}, 27^{\circ}$ and $32^{\circ} \mathrm{C}$ with the daily cycle of $14 \mathrm{~h}$ light $(>95 \% \mathrm{RH})$ followed by $10 \mathrm{~h}$ of darkness (> 95\% RH).

Blast spot or lesion size was measured through software i.e., Assess 2.0 (Lakhdar, 2008). With the same sample, spores number was counted using a haemocytometer under the microscope (Ghatak et al., 2013).

\section{Results and Discussion}

\section{Selection criteria for selecting of temperatures}

Based on infection ability model three temperatures were selected for this study i.e., $22^{\circ}, 27^{\circ}$ and $32^{\circ} \mathrm{C}$. Infection ability $(y)$ model can explains sporulation and lesion development rate at temperature $\mathrm{T}\left({ }^{\circ} \mathrm{C}\right) y=r$ $[T]=0.24 \times[(34.1-T) / 6.6] \quad[(T-$ 7.9)/19.6 $]^{2.9697}$. These temperatures were designated as suboptimal $\left(22^{\circ} \mathrm{C}\right)$, optimal $\left(27^{\circ} \mathrm{C}\right)$ and supra-optimal $\left(32^{\circ} \mathrm{C}\right)$ temperature for M. oryzae (Viswanath, 2015).

Effect of temperature on growth of $M$. oryzae in RSEDOMA media

Temperature effect significantly $M$. oryzae growth in media. Maximum growth was observed at $27^{\circ} \mathrm{C}(41.7 \mathrm{~mm})$, compare to $32^{\circ} \mathrm{C}(26.5 \mathrm{~mm})$ and $22^{\circ} \mathrm{C}(24.5 \mathrm{~mm})$. At optimal temperature $\left(27^{\circ} \mathrm{C}\right)$ growth was nearly double in media compare to $22^{\circ} \mathrm{C}$ and $32^{\circ} \mathrm{C}$. Similarly, maximum rate observed at $27^{\circ} \mathrm{C}$ (4.2 mm/day), compare to $32^{\circ} \mathrm{C}$ (2.6 $\mathrm{mm})$ and $22^{\circ} \mathrm{C}(2.4 \mathrm{~mm})$ (Fig. 1 and Table 1$)$.

Effect of temperature on lesion size of $M$. oryzae on PRR 78 variety

Lesion size developed on PRR 78 variety by $M$. oryzae were significantly influenced by temperature. As temperature increased lesion size developed up to a temperature and later on decreases. Maximum lesion size was observed at $27^{\circ} \mathrm{C}\left(45 \mathrm{~mm}^{2}\right)$, compare to $22^{\circ} \mathrm{C}$ $\left(7.5 \mathrm{~mm}^{2}\right)$ and $32^{\circ} \mathrm{C}\left(5.5 \mathrm{~mm}^{2}\right)$. Lesion size developed at optimal temperature $\left(27^{\circ} \mathrm{C}\right)$ were nearly 6 times higher compare $22^{\circ} \mathrm{C}$ and 9 time higher compare $32^{\circ} \mathrm{C}$. As results showed higher temperature $32^{\circ} \mathrm{C}$ was not suitable for blast symptom development and growth. Similar, maximum lesion development rate was observed at $27^{\circ} \mathrm{C}\left(3.21 \mathrm{~mm}^{2} /\right.$ day $)$, 
compare to $22^{\circ} \mathrm{C}\left(0.54 \mathrm{~mm}^{2} /\right.$ day $)$ and $32^{\circ} \mathrm{C}$ $\left(0.39 \mathrm{~mm}^{2} /\right.$ day) (Fig. 1and Table 1).

Effect of temperature on sporulation of $M$. oryzae in RSEDOMA media

Temperatures were affected tremendously sporulation of $M$. oryzae in RSEDOMA media. Maximum sporulation was observed at $27^{\circ} \mathrm{C}\left(2.22 \times 10^{5} \mathrm{spores} / \mathrm{ml}\right.$ of sterilize water $)$ compare to $22^{\circ} \mathrm{C}\left(1.67 \times 10^{5}\right.$ spores $/ \mathrm{ml}$ of sterilize water $)$ and $32^{\circ} \mathrm{C}\left(1.47 \times 10^{5}\right.$ spores $/ \mathrm{ml}$ of sterilize water). Sporulation at optimal temperature was 1.51 times more compare to $32^{\circ} \mathrm{C}$ temperature and 1.33 times more compare to $22^{\circ} \mathrm{C}$. That mean at higher temperature sporulation efficiency decreased significantly. Maximum sporulation rate was observed at $27^{\circ} \mathrm{C}\left(0.22 \times 10^{5}\right.$ spores $/ \mathrm{ml}$ of sterilize water/day) compare to $22^{\circ} \mathrm{C}$ $\left(0.17 \times 10^{5}\right.$ spores $/ \mathrm{ml}$ of sterilize water/day $)$ of sterilize water $)$ and $32^{\circ} \mathrm{C}\left(0.15 \times 10^{5}\right.$ spores $/ \mathrm{ml}$ of sterilize water/day) (Fig. 2 and Table 2).

Table.1 Effects of temperature on M. oryzae growth

\begin{tabular}{|c|c|l|l|l|}
\hline \multirow{2}{*}{$\begin{array}{c}\text { Temperatures } \\
(\end{array}$} & \multicolumn{4}{|c|}{ Growth and growth rate of M. oryzae } \\
\cline { 2 - 5 } & \multicolumn{2}{|c|}{ RSEDOMA media } & \multicolumn{2}{c|}{ PRR78 variety } \\
\cline { 2 - 5 } & $\begin{array}{l}\text { Growth in } \\
\text { RSEDOMA } \\
\text { media }(\mathbf{m m})\end{array}$ & $\begin{array}{l}\text { Growth } \\
\text { rate } \\
(\mathbf{m m} / \mathbf{d a y})\end{array}$ & $\begin{array}{l}\text { Lesion size } \\
\left(\mathbf{m m}^{2}\right)\end{array}$ & $\begin{array}{l}\text { Lesion } \\
\text { development rate } \\
\left(\mathbf{m m}^{2} / \mathbf{D a y}\right)\end{array}$ \\
\hline $\mathbf{2 2}$ & $24.5 \pm 4.8^{\mathrm{c}}$ & 2.4 & $7.5 \pm 0.8^{\mathrm{b}}$ & 0.54 \\
\hline $\mathbf{2 7}$ & $41.7 \pm 5.8^{\mathrm{a}}$ & 4.2 & $45 \pm 6.8^{\mathrm{a}}$ & 3.21 \\
\hline $\mathbf{3 2}$ & $26.5 \pm 4.2^{\mathrm{b}}$ & 2.6 & $5.5 \pm 0.6^{\mathrm{b}}$ & 0.39 \\
\hline $\mathrm{CD}$ at $1 \%$ & 1.12 & & 3.23 & \\
\hline
\end{tabular}

Table.2 Effects of temperature on M. oryzae sporulation

\begin{tabular}{|c|c|c|c|c|}
\hline \multirow{2}{*}{ Temperatures $\left({ }^{\circ} \mathbf{C}\right)$} & \multicolumn{4}{|c|}{ Sporulation and rate of sporulation of M. oryzae } \\
\cline { 2 - 5 } & $\begin{array}{l}\text { RSEDOMA media } \\
\begin{array}{l}\text { Sporulation } \\
\text { (spores/ml of } \\
\text { sterilize water) }\end{array}\end{array}$ & $\begin{array}{l}\text { Rate of } \\
\text { sporulation } \\
\text { (spores/ml } \\
\text { of sterilize } \\
\text { water/day) }\end{array}$ & $\begin{array}{l}\text { Sporulation } \\
\text { (spores/mm } \mathbf{2}^{2} \text { of } \\
\text { lesion) }\end{array}$ & $\begin{array}{l}\text { Rate of } \\
\text { sporulation } \\
\text { (spores/mm } \\
\text { of lesion/day) }\end{array}$ \\
\hline $\mathbf{2 2}$ & $1.67 \times 10^{5 \mathrm{~b}}$ & $0.17 \times 10^{5}$ & $1.12 \times 10^{5 \mathrm{~b}}$ & $0.813 \times 10^{5}$ \\
\hline $\mathbf{2 7}$ & $2.22 \times 10^{5 \mathrm{a}}$ & $0.22 \times 10^{5}$ & $24.1 \times 10^{5 \mathrm{a}}$ & $1.721 \times 10^{5}$ \\
\hline $\mathbf{3 2}$ & $1.47 \times 10^{5 \mathrm{c}}$ & $0.15 \times 10^{5}$ & $0.66 \times 10^{5 \mathrm{c}}$ & $0.004 \times 10^{5}$ \\
\hline $\mathrm{CD}(\mathrm{P}=0.01)$ & 1322.6 & & 862.5 & \\
\hline
\end{tabular}




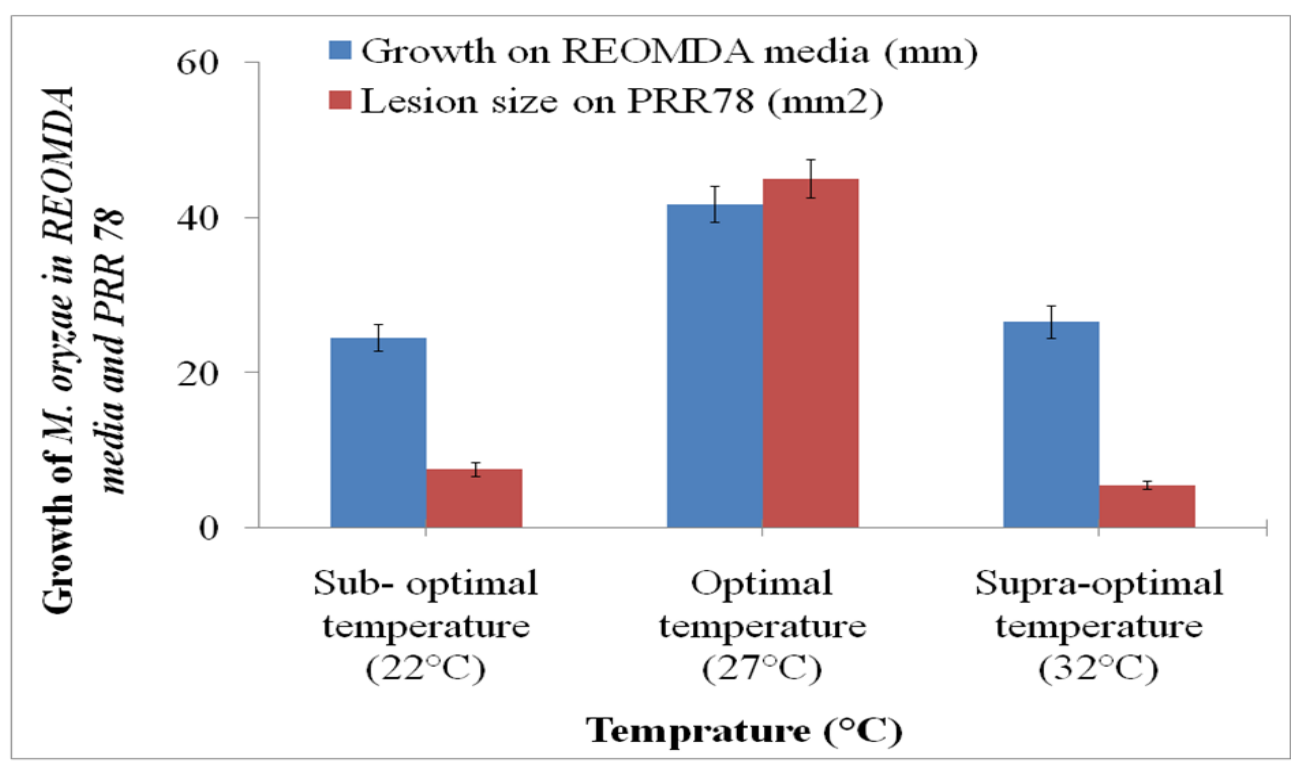

Fig. 1. Effects of temperature on $M$. oryzae growth

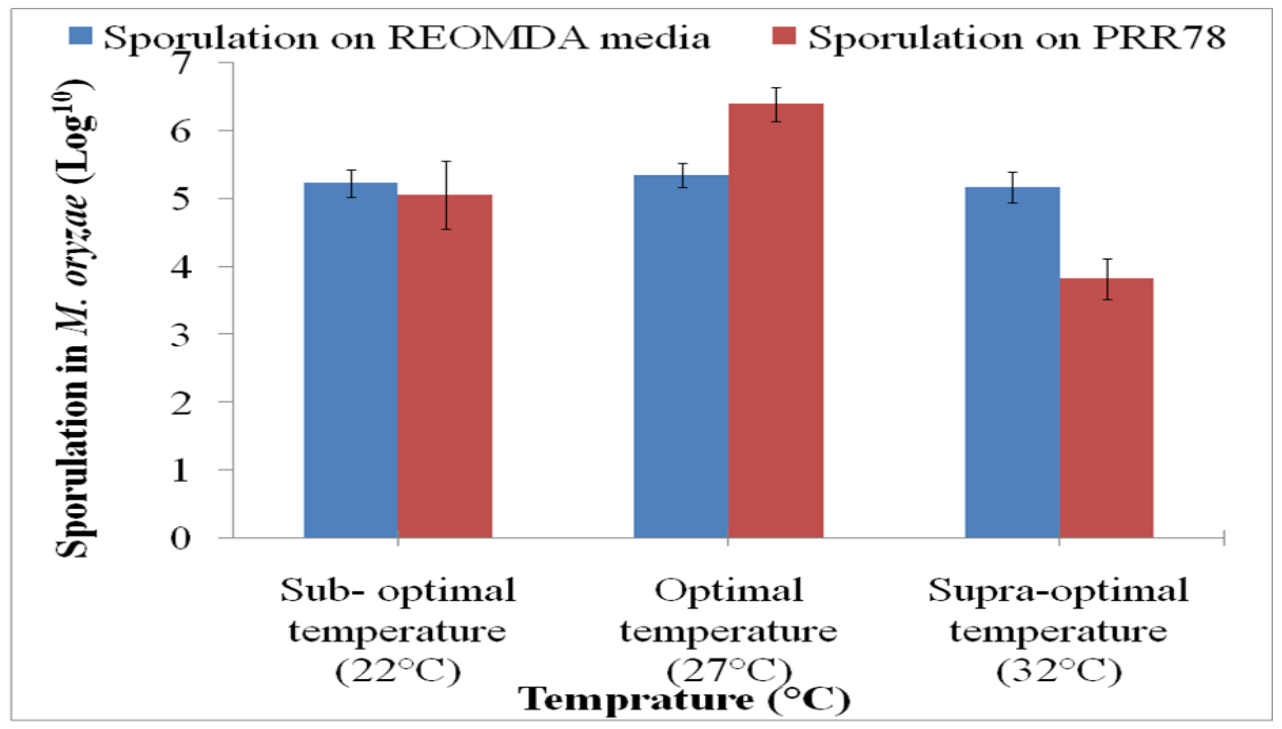

Fig. 2 Effect of temperature on $M$. oryzae sporulation

Effect of temperature on sporulation of $M$. oryzae in PRR78 variety

In susceptible variety PRR78, M. oryzae was highly sporulated at optimal temperature $\left(27^{\circ} \mathrm{C}\right)$. Sporulation was affected significantly by temperature. Maximum sporulation was observed at $27^{\circ} \mathrm{C}\left(24.1 \times 10^{5}\right.$ spores/ $\mathrm{mm}^{2}$ of lesion) of compare to $22^{\circ} \mathrm{C}$ $\left(1.12 \times 10^{5}\right.$ spores/ $\mathrm{mm}^{2}$ of lesion $)$ and $32^{\circ} \mathrm{C}$ $\left(0.66 \times 10^{5}\right.$ spores/ $\mathrm{mm}^{2}$ of lesion $)$. At $27^{\circ} \mathrm{C}$ sporulation was nearly 365 times higher than $22^{\circ} \mathrm{C}$ and 21.5 times higher than $22^{\circ} \mathrm{C}$. At $27^{\circ} \mathrm{C}$ sporulation rate was observed maximum $\left(1.721 \times 10^{5}\right.$ spores/ $\mathrm{mm}^{2}$ of lesion/day) compare to $22^{\circ} \mathrm{C} \quad\left(0.813 \times 10^{5}\right.$ spores/ $\mathrm{mm}^{2}$ of lesion/day) and $22^{\circ} \mathrm{C}$ $\left(0.004 \times 10^{5} \mathrm{spores} / \mathrm{mm}^{2}\right.$ of lesion/day). It was observed that at the higher temperature, sporulation of M. oryzae was inhibited (Fig. 2 and Table 2). 
Temperature influence on growth and sporulation of $M$. oryzae was observed at three temperatures i.e., $22^{\circ} \mathrm{C}, 27^{\circ} \mathrm{C}$ and $32^{\circ} \mathrm{C}$, where they were unknown. M. oryzae showed a typical kind of growth pattern. It observed that growth and sporulation of $M$. oryzae effected by temperature on RSEDOMA media as well as susceptible rice plants. The growth of fungus in RSEDOMA media and lesion development in susceptible plant both were observed maximum at optimal temperature $\left(27^{\circ} \mathrm{C}\right)$ and compare to sub optimal $\left(22^{\circ} \mathrm{C}\right)$ and supra-optimal temperatures $\left(32^{\circ} \mathrm{C}\right)$. Interestingly less growth was observed in susceptible plant compare to media in both $22^{\circ} \mathrm{C}$ and $32^{\circ} \mathrm{C}$ temperatures, that indicate it may be by operating PTI in the plant (Boyd et al., 2013) or temperature effects on pathogen (Luo et al., 1998) or cumulative of both. Leaf blast infection and host evasion profoundly affected by temperature (Luo et al., 1998) and that play a key role in the epidemic of leaf blast (Kato and Kozaka, 1974; Teng et al., 1990). Similarly, at $16^{\circ} \mathrm{C}$ and $20^{\circ} \mathrm{C}$ lesions developed slowly than at $25^{\circ} \mathrm{C}$ and 32 ${ }^{\circ} \mathrm{C}$ (Kato and Kozaka, 1974) and higher temperature restricted lesion development (Yoshino and Yamaguchi, 1970). For successful infection, $M$. oryzae produce appressorium, that also tremendously inhibited at the higher temperature $\left(34^{\circ} \mathrm{C}\right)$ which indicated that pathogen growth was significantly reduced at the higher temperature (Viwsanath et al., 2015). Sporulation in $M$. oryzae also showed the same kind of trend like the growth of $M$. oryzae. Extremely decline in sporulation at the higher temperature $\left(32^{\circ} \mathrm{C}\right)$ indicated that pathogen unable to infect host plant at the higher temperature. The cardinal temperatures for sporulation are about 9$12^{\circ} \mathrm{C}, 25-28^{\circ} \mathrm{C}$ and $34-35^{\circ} \mathrm{C}$ (Henry and Anderson, 1948) and range of temperature for sporulation was reported as $18-32^{\circ} \mathrm{C}$ (Madden and Ellis, 1988). Sporulation and lesion development are the component of infection process and they are the key determinants of rice blast epidemics. Results of this experiment showed that temperature has the huge impact on both sporulation and lesion development. According to infection model, each degree changed in temperature lead to change nearly 0.20 unit of sporulation and lesion development rate and results of this studies showed that each degree changed in temperature changed growth in media $(0.36 \mathrm{~mm})$, lesion development $\left(0.53 \mathrm{~mm}^{2}\right)$, sporulation in media (1000 spores) and plant (17800 spores). As we know, the temperature will be rise by $1.5-4.8^{\circ} \mathrm{C}$ by the end of this century, globally (IPCC 2014) and presently rice is cultivated in regions where temperatures are optimal for growth $\left(28^{\circ} \mathrm{C} / 22^{\circ} \mathrm{C}\right)$. Sporulation and lesion development are the main component of rice leaf blast infection process. As the rise in temperature leads to increase in growth and sporulation of $M$. oryzae, it's to be expected to enhance in aggressiveness of $M$. oryzae that leads to create rice blast epidemic in the tropical and subtropical regions of the world. Therefore, due to climate change or enhancement in temperature could have a huge impact on rice blast epidemics. Specially, in South India, rabi rice is growing with temperature range $18^{\circ}$ to $24^{\circ} \mathrm{C}$, so there slight increases in temperature lead to enhancement in aggressiveness of fungus that may have a huge impact on rice harvest of South India. Therefore, the impact of temperature on infection components may use for development of crop loss assessment models, rice blast prediction models, evaluation of genotypes for the development of future plant diseases managements strategies.

\section{Acknowledgement}

We are very much thankful to NICRA, ICAR-Indian Agricultural Research Institute, 
New Delhi-110012, India for providing financial assistance.

\section{References}

Agrios, G.N. 2005. Plant Pathology, $5^{\text {th }}$ edi. Academic Press, San Diego, pp. 125-170.

Boyd, L.A., C. Ridout, D.M. O'Sullivan, J.E. Leach and Leung, H. 2013. Plantpathogen interactions: disease resistance in modern agriculture. Trends in Genetics, 29(4): 233-240.

Burdon, J.J., P.H. Thrall and Ericson, A.L. 2006. The current and future dynamics of disease in plant communities. Annual Rev. Phytopathol., 44: 19-39.

Chakraborty, S. 2005. Potential impact of climate change on plant-pathogen interactions. Australasian Plant Pathol., 34: 443-448.

Eastburn, D.M., A.J. McElrone and Bilgin, D.D. 2011. Influence of atmospheric and climatic change on plant-pathogen interactions. Plant Pathol., 60(1): 54-69.

El Refaei, M.I. 1977. Epidemiology of rice blast disease in tropics with special reference to the leaf wetness in relation to disease development. Ph.D. Thesis. Indian Agricultural Research Institute, New Delhi, India.

FAO. 2014.

Ghatak, A., L. Willocquet, S. Savary and Kumar, J. 2013. Variability in aggressiveness of rice blast (Magnaporthe oryzae) isolates originating from rice leaves and necks: a case of pathogen specialization. PLOS One, 8: 1-14.

Ghini, R., W. Bettiol and Hamada, E. 2011. Diseases in tropical and plantation crops as affected by climate changes: Current Knowledge and perspectives. Plant Pathol., 60: 100-112.

Henry, B.W., and Anderson, A.L. 1948. Sporulation by Pyricularia oryzae. Phytopathol., 88: 265-278.

IPCC. 2007. Climate Change (2007): Synthesis Report. Contribution of working Groups
I, II and III to the Fourth Assessment Report of the Intergovernmental Panel on climate change [Core Writing Team, Pachauri, R.K and Reisinger, A. (eds.)]. IPCC, Geneva, Switzerland, pp. 104.

IPCC. 2014. IPCC-II-Intergovernmental Panel on Climate Change. Impacts, adaptation, and vulnerability. Part A: Global and sectoral aspects. Contribution of Working Group II to the $5^{\text {th }}$ Assessment Report of the IPCC. Cambridge University Press, Cambridge.

Kato, H. 1974. Epidemiology of rice blast disease. Review of Plant Protection Res., 7: $1-20$.

Kato, H., and Kozaka, T. 1974. Effect of temperature on lesion enlargement and sporulation of Pyricularia oryzae in rice leaves. Phytopathol., 64: 828-830.

Kato, H., T. Sasaki and Koshimizu, Y. 1970. Potential for conidium formation of Pyricularia oryzae in lesions on leaves and panicle of rice. Phytopathol., 60: 608-612.

Kingslover, C.H., T.H. Barksdale and Marchetti, M.A. 1984. Rice blast epidemiology. Bulletin of the Pennsylvania Agricultural Experiment Station, 853. pp. 1- 33.

Lakhdar, L., 2008. Asses 2.0. Image analysis software for plant disease quantification, St. Paul Minnesota USA APS press.

Legreve, A., and Duveiller, E. 2010. Preventing Potential Diseases and Pest Epidemics under a Changing Climate. In: Reynolds, M.P., Ed., Climate Change and Crop Production, CABI Publishing, Wallingford, pp. 50-70.

Liang, W.J. 1979. Effects of meteorological factors on spore germination, appressorium formation and invasion of the rice blast fungus Pyricularia oryzae. Nat. Sci. Council Monthl., 7: 810-819.

Luo, Y., P.S. Teng, N.G. Fabellar and TeBeest, D.O. 1998. Risk analysis of yield losses caused by rice leaf blast associated with temperature changes above and below for five Asian countries. Agriculture, Ecosystem and Environ., 68: 197-205. 
Madden, L.V., and Ellis, M.A. 1988. How to develop plant disease forecasters? In: Experimental techniques in plant disease epidemiology. Kranz, J. and Rotem, J., Editors, Springer-Verlag, New York, pp. 191-208.

Nisikado, Y. 1927. Studies on rice blast disease. Japan J. Bot., 3: 239-244.

Padmanabhan, S.Y. 1965. Studies on forecasting outbreaks of blast disease of rice. Proceedings of the Indian Academy of Sciences - Section B, 62(3): 117-129.

Rahnema, I. 1978. Simulation of the effect of different water regime on germination and formation of appressoria of Pyricularia oryzae. J. Plant Dis. Protection, 86: 315-219.

Sharma, T.R., M.S. Madhav, B.K. Singh, P. Shanker, T.K. Jana, V. Dalal, A. Pandit, A. Singh, K. Gaikwad, H.C. Upreti and Singh, N. K. 2005. High-resolution mapping cloning and molecular characterization of the $P i-k h$ gene of rice, which confers resistance to Magnaporthe grisea. Mol. Genetics and Genomics, 274: 569-578.

Sueda, H. 1928. Studies on the rice blast disease. Report of the Department of Agriculture Government Research Institute of Formosa. 36: 1-130.

Suzuki, H. 1969. Effect of temperature on germination of conidia and appressorium formation of Pyricularia oryzae. Annual Report of Plant Protection in North Japan, 17: 6-9.

Talbot, N.J., D.J. Ebbole and Hamer, J.E. 1993. Identification and characterization of $M P G 1$, a gene involved in pathogenicity from the rice blast fungus
Magnaporthe grisea. Plant Cell, 5: 15751590.

Teng, P.S., H.W. Klein-Gebbinck and Pinnsschmidt, H. 1990. An analysis of the blast pathosystem to guide modelling and forecasting, In:Rice blast modelling and forecasting, International Rice Research Institute, 1990, Phillippines, pp.1-29.

Viswanath, K., T. Sharma, P. Sinha and Kumar, $\mathrm{M}, 2015$. Influence of temperature on appressorial formation in $M$. grisea in relation to cAMP- dependent PKA Activity. J. Pure and Appl. Microbiol., 9: 2903-2912.

Viswanath, K. 2015. Effect of elevated temperature on rice blast (Magnaporthe oryzae) infection and expression levels of pathogenicity genes. Ph.D. thesis. Indian Agricultural Research Institute, New Delhi, India.

Wilson, R.A., and Talbot, N.J. 2009. Under pressure: investigating the biology of plant infection by Magnaporthe oryzae. Nature Rev. Microbiol., 7: 185-195.

Yaegashi, H., and Hebert, T.T. 1976. Perithecial development and nuclear behaviour in Pyricularia. Phytopathol., 66: 122-126.

Yoshino, R. 1972. Influence of temperature on the incubation period of Pyricularia oryzae and early detection on lesions by staining with iodine potassium iodide. Rev. Plant Protection Res., 5: 105-107.

Yoshino, R., and Yamaguchi, T. 1970. Relation between air temperatures after colonization and diseases development. Annals of Phytopathol. Soc. Japan, 36: 156.

\section{How to cite this article:}

Laxman Singh Rajput, Taru Sharma, Puchakayala Madhusudhan and Parimal Sinha. 2017. Effect of Temperature on Growth and Sporulation of Rice Leaf Blast Pathogen Magnaporthe oryzae. Int.J.Curr.Microbiol.App.Sci. 6(3): 394-401.

doi: https://doi.org/10.20546/ijcmas.2017.603.045 